\title{
Pengaruh Model Penemuan Terbimbing Berbantuan WEB Terhadap Keterampilan Berpikir Kritis Matematis Siswa Kelas X
}

\section{Lalu Irfan Abdul Manaf ${ }^{1 *}$, Nyoman Sridana ${ }^{2}$, Arjudin ${ }^{2}$, Sripatmi ${ }^{2}$}

\author{
${ }^{1}$ Mahasiswa Pendidikan Matematika, FKIP, Universitas Mataram, Mataram \\ ${ }^{2}$ Dosen Pendidikan Matematika, FKIP, Universitas Mataram, Mataram
}

laluirfann@gmail.com

Diterima: 17-12-2021; Direvisi: 30-12-2021; Dipublikasi: 30-12-2021

\begin{abstract}
The background of this research is, there is no learning model that can optimally support critical thinking skills, so it takes an innovative learning model. In this case, the researchers used web helped to guide discovery learning model to improve the critical thinking skills of the student in class X SMAN 4 Praya in academic year 2019/2020. This study aimed to find an effect of web assisted guided discovery learning on trigonometry material to critical thinking ability of the student in class X SMAN 4 Praya in academic year 2019/2020. This study use a quantitative research approach to the type of experimental research. In this experiment the researchers used a quasi-experimental, and uses two classes as a research, the experimental class and control class. The population of this research is all the student in class X SMAN 4 Praya and and choose two class as a sample class that is X MIPA 5 as a experimental class and X MIPA 3 as control class. Student in experimental class used web assisted guided discovery learning model and in control class used guided discovery without web assisted. The result of the research showed that the average of critical thinking ability in the experimental class is better than control class which is in the experimental class is in the less effective category and control class in ineffective category.
\end{abstract}

Keywords: quasi experiment; control class; experiment class; critical thinking.

\begin{abstract}
Abstrak
Penelitian ini dilatar belakangi oleh belum adanya suatu model pembelajaran yang dapat menunjang keterampilan berpikir kritis secara optimal, sehingga dibutuhkan suatu model pembelajaran yang inovatif. Dalam hal ini peneliti menggunakan model pembelajaran penemuan terbimbing berbantuan web untuk meningkatkan keterampilan berpikir kritis siwa kelas X SMAN 4 Praya tahun 2019/2020. Penelitian ini bertujuan untuk mengetahui apakah terdapat pengaruh penggunaan model penemuan terbimbing terdapat keterampilan berpikir kritis matematis siswa kelas X SMAN 4 Praya tahun 2019/2020. Penelitian ini menggunakan pendekatan kuantitatif dengan jenis penelitian eksperimen. Dalam ekeperimen ini peneliti menggunakan eksperimen semu, dan dipilih dua kelas sbegai penelitian, yaitu kelas eksperimen dan kelas kontrol. Populasi pada penelitian ini yaitu seluruh siswa kelas X SMAN 4 Praya, dan dipilih dua kelas sebagai kelas sample yakni kelas X MIPA 5 sebagai kelas eksperimen dan X MIPA 3 sebagai kelas kontrol. Siswa pada kelas X MIPA 5 menggunakan model penemuan terbimbing berbantuan web, sedangkan siswa pada kelas X MIPA 3 Menggunakan model penemuan terbimbing tanpa bantuan web. Hasil penelitian ini menunjukan bahwa rata-rata keterampilan berpikir krtitis pada kelas eksperimen lebih baik dibandingkan dengan kelas kontrol. Dimana kelas eksperimen berada pada katagori kurang efektif dan kelas kontrol berada pada katagori tidak efektif.
\end{abstract}

Kata Kunci: eksperimen semu; kelas kontrol; kelas eksperimen, berpikir kritis. 


\section{PENDAHULUAN}

Matematika berasal dari bahasa latin mathemata yang berarti belajar atau hal yang dipelajari. Dalam bahasa belanda disebut wiskunde atau ilmu pasti yang kesemuanya berkaitan dengan penalaran (Supatmono, Catur, 2009). Matematika merupakan ilmu pasti yang dipelajari mengenai pola pikir, pembukrian secara logika, pola mengorganisasikan dan beberapa konsep mengenai bilangan yang mempunyai hubungan satu dengan yang lain dengan jumlah yang banyak. Fathani menyatakan bahwa matematika itu penting sebagai alat bantu, sebagai ilmu (bagi ilmuan), sebagai pembentuk sikap maupun sebagai pembimbing pola pikir (Maulana, 2008).

Hasil belajar rendah menjadi salah satu masalah yang ditemukan di sekolah siswa di sekolah sering menjadi permasalahan belajar dalam pemahaman materi. Masalah ini dapat dikarenakan faktor belajar siswa yang kurang efektif, bahkan siswa sendiri tidak merasa termotivasi dalam mengikuti pembelajaran di kelas, sehingga siswa tidak memahami materi. Kecenderungan pembelajaran yang kurang menarik merupakan ketidakpahaman guru terhadap kebutuhan siswanya, baik dalam karakteristik maupun dalam pengembangan ilmu (Daryanto, 2016). Untuk itu guru harus memahami perilaku siswa dengan mencoba memahami persepsi siswa, sehingga siswa mau merubah perilakunya untuk belajar (Turmuzi, M, 2012).

Dalam upaya peningkatan kualitas pendidikan dewasa ini telah dikembangkan penggunaan teknologi informasi di kelas. Metode pembelajaran yang dulunya bersifat tradisional perlahan-lahan mulai ditinggalkan dan digantikan dengan metode pembelajaran yang lebih modern. Penggunan media teknologi dalam kegiatan pembelajaran sekarang ini bukan lagi suatu yang luar biasa. Perkembangan teknologi informasi beberapa tahun belakangan ini berkembangan dengan kecepatan yang sangat tinggi sehingga dengan perkembangan ini telah mengubah pradigma masyarakat dalam mencari dan mendapatkan informasi, yang tidak lagi terbatas pada informasi surat kabar, audio visual dan elektronik, tetapi juga sumber-sumber informasi lainnya yang salah satu diantaranya melalui jaringan internet. Teknologi informasi dapat menjadi media penyajian ide, gagasan dan materi pembelajaran. Beberapa bagian dalam unsur pembelajaran ini mendapatkan sentuhan media teknologi informasi, sehingga mempermudah pelaksanaan pembelajaran (Irawati, Titiek, 2010).

Integrasi teknologi informasi kedalam pembelajaran salah satunya dalam bentuk pembelajaran berbasis website. Menurut Gora, website adalah sebuah jaringan global dari jutaan halaman informasi yang berisi teks, gambar, dan link ke halaman lain yang menjadi bagian informasi. Halaman dari website biasa dia akses melalu sebuah URL yang biasa disebut Homepage. URL ini mengatur para pembaca dan memberitahu mereka susunan keseluruhan dan bagaimana arus informasi ini berjalan (Rosha Media, Irwan Jas, Nilawasti, 2012).

Kemampuan berpikir kritis dapat dikembangkan melalui pembelajaran matematika di sekolah ataupun perguruan tinggi, yang menitik beratkan pada sistem, struktur, konsep, 
prinsip, serta kaitan yang ketat antara suatu unsur dan unsur lainnya (Maulana, 2008). Ruggiero menyatakan berpikir kritis merupakan keterampilan hidup, bukan hobi di bidang akademik (Mujib, Mardiyah, 2017). Selanjutnya Steven mengemukakan bahwa proses berpikir kritis dapat digambarkan seperti metode ilmiah, yaitu mengidentifikasi masalah, merumuskan hipotesis, mencari dan mengumpulkan data yang relevan, menguji hipotesis secara logis, melakukan evaluasi dan membuat kesimpulan yang reliabel (Arikunto, Suharsimi, 2006).

Untuk mengaktifkan siswa dalam pembelajaran, perlu adanya model pembelajaran yang dapat mendorong siswa lebih giat dalam pembelajarnnya. Dalam hal ini diharapkan model pembelajaran yang digunakan dapat mengatasi permasalahan yang sering muncul pada proses pembelajaran, dengan demikian salah satu proses pembelajaran yang dapat meningkatkan kemampuan berpikir kritis dan motivsi siswa dalam belajar adalah dengan menggunakan model pembelajaran termbimbing (Guided inquiry). Model ini diharapkan mampu mengatasi beberapa persoalan dalam pembelajaran matematika di SMAN 4 Praya.

\section{METODE PENELITIAN}

Penelitian ini dilakukan di SMAN 4 Praya pada semester genap tahun ajaran 2019/2020. Jenis penelitian yang digunakan adalah Quasi eksperimen dengan menggunakan pretestposttest control group design (Emzir, 2017). Dalam desain penelitian ini digunakan dua kelompok yaitu kelompok eksperimen yang belajar menggunakan model penemuan terbimbing berbantuan web dan kelas kontrol yang belajar dengan model penemuan terbimbing tanpa bantaun web. Dua kelompok diberikan pretest diawal dan posttest diakhir pembelajaran. Variabel bebas dalam penelitian ini yaitu model penemuan terbimbing berbantuan web dan variabel terikat yaitu keterampilan berpikir kritis siswa. Teknik pengumpulan data yang digunakan pada penelitian ini adalah teknik tes. Tes adalah serentetan pertanyaan atau latihan serta alat lain yang digunakan untuk mengukur keterampilan, pengetahuan intelejensi, kemampuan atau bakat yang dimiliki oleh individu atau kelompok (Abdullah, In Hi, 2013). Analisis data yang digunakan adalah uji perbedaan dua sample dan uji N-Gain skor. Uji N-Gain digunakan untuk mengetahui seberapa besar pengaruh model penemuan terbimbing berbantuan web terhadapa keterampilan berikir kritis siswa. Adapun kriteria uji gain yang digunakan adalah sebagai berikut:

Tabel 1. Kategori Tafsiran Efektifitas N-Gain

\begin{tabular}{cc}
\hline Rata-rata N-Gain & Tafsiran \\
\hline$\overline{\mathbf{G}}<\mathbf{4 0}$ & Tidak efektif \\
\hline $\mathbf{4 0} \leq \overline{\mathbf{G}}<\mathbf{5 5}$ & Kurang efektif \\
\hline $\mathbf{5 5} \leq \overline{\mathbf{G}}<\mathbf{7 6}$ & Cukup Efektif \\
\hline$\overline{\mathbf{G}} \geq \mathbf{7 6}$ & Efektif \\
\hline
\end{tabular}

\section{HASIL DAN PEMBAHASAN}




\subsection{Validitas}

Instrumen yang digunakan dalam penelitian ini berjumlah 3 butir. Dimana instrument tersebut divalidasi terlebih dahulu sebelum digunakan untuk mengukur kemampuan komunikasi matematis tertulis siswa. Dari keempat butir instrument yang di validasi, keempat instrument tersebut dinyatakan valid secara isi dan empiris.

\section{Validitas isi}

Sebelum diberikan kepada siswa, soal tes terlebih dahulu divalidasi oleh validator. Validasi dilakukan salah satu dosen program studi Pendidikan Matematika Universitas Mataram. Hal ini dilakukan untuk memberikan masukan dan saran bagi penliti terhadap instrumen sehingga instrument tersebut layak untuk digunakan. Dalam penelitian ini validator adalah salah satu dosen pendidikan Matematika. Setelah diberikan saran dan masukan dan dilakukan revisi terhadap instrument tersebut maka intstrumen dinyatakan layak untuk digunakan.

\section{Validitas Empiris}

Setelah dilakukan validitas isi oleh validator, setelah itu dilakukan uji validitas empiris. Soal-soal tes keterampilan berpikir kritis matematis yang sudah diujikan sebelumya telah diuji validitasnya pada 35 siswa kelas XI MIA 2 SMAN 4 Praya. Jumlah soal yang diuji sebanyak 3 soal uraian yang telah mewakili setiap indicator dari materi yang diujikan.

Tabel 2. Hasil Uji Validitas Instrumen

\begin{tabular}{|c|c|c|c|c|}
\hline Butir & r hitung & r tabel & Keputusan uji & kesimpulan \\
\hline 1 & 0,680 & 0.344 & $r$ hitung $>r$ tabel & Valid \\
\hline $2 \mathbf{a}$ & 0,318 & & $r$ hitung $>r$ tabel & Valid \\
\hline $2 b$ & 0,364 & & $r$ hitung $>r$ tabel & Valid \\
\hline 3 & 0,739 & & $r$ hitung $>r$ tabel & Valid \\
\hline
\end{tabular}

Berdasarkan tabel 2 diatas diketahui bahwa setiap butir soal valid/layak untuk digunakan dalam penelitian.

\subsection{Hasil Analisis Deskriptif}

Rangkuman skor pretest-posttest kelas kontrol dan kelas eksperimen dapat dilihat pada tabel berikut:

Tabel 3. Statistik Deskriptif

\begin{tabular}{lllll}
\hline Kelompok & \multicolumn{2}{l}{ Data Hasil Pretest } & \multicolumn{2}{l}{ Data Hasil Posttest } \\
\cline { 2 - 5 } Data & $\begin{array}{l}\text { Kelas } \\
\text { Kontrol }\end{array}$ & $\begin{array}{l}\text { Kelas } \\
\text { Eksperimen }\end{array}$ & $\begin{array}{l}\text { Kelas } \\
\text { Kontrol }\end{array}$ & $\begin{array}{l}\text { Kelas } \\
\text { Eksperimen }\end{array}$ \\
\hline $\begin{array}{l}\text { Skor Tertinggi } \\
\left(\boldsymbol{X}_{\text {max }}\right)\end{array}$ & 65 & 60 & 57 & 82 \\
\hline $\begin{array}{l}\text { Skor Terendah } \\
\left(\boldsymbol{X}_{\text {min }}\right)\end{array}$ & 10 & 10 & 10 & 41 \\
\hline
\end{tabular}




\begin{tabular}{lllll}
\hline Rata-rata $(\overline{\boldsymbol{X}})$ & 29,25 & 34,14 & 34.75 & 60.48 \\
\hline $\begin{array}{l}\text { Standar } \\
\text { Deviasi (S) }\end{array}$ & 13,854 & 14,425 & 13,418 & 10,151 \\
\hline Varians (S 2 ) & 191,933 & 208,080 & 180,042 & 103,042 \\
\hline $\begin{array}{l}\text { Jumlah Siswa } \\
\text { (n) }\end{array}$ & 32 & 31 & 32 & 31 \\
\hline
\end{tabular}

Bedasarkan Tabel 3. didapatkan bahwa rata-rata pretest kelas kontrol lebih kecil dari kelas eksperimen namun tidak signifikan perbedaannya, sedangkan pada saat posttest rata-rata kelas eksperimen lebih besar dibanding dengan kelas kontrol dan memiliki perbedaannya yang signifikan.

\subsection{Hasil Analisis Inferensial}

Analisis selanjutnya adalah analisis inferensial. Untuk mencari perbedaan peningkatan $\mathrm{N}$-Gain kemampuan berpikir kritis diperoleh dengan cara membandingkan $\mathrm{N}$-Gain kelas eksperimen dengan kelas kontrol. Tapi terlebih dahulu dilakukan uji normalitas dan homogenitas terhadap skor N-Gain tersebut. Hasil perhitungan N-Gain pretest dan posttest kelas kontrol dan kelas ekperimen diberikan pada tabel berikut.

Tabel 4. Deskripsi skor N-Gain kelas eksperimen dan kelas Kontrol

\begin{tabular}{lllllll}
\hline & N & Minimum & Maximum & Mean & $\begin{array}{l}\text { Std. } \\
\text { Dev }\end{array}$ & Variance \\
\hline Kelas & 3 & 0 & 67.27 & 40.11 & 17.108 & 292.701 \\
Eksperimen & 1 & & & 9 & & \\
Kelas Kontrol & 3 & 0 & 47.06 & $\begin{array}{l}9.653 \\
6\end{array}$ & 10.435 & 109.276 \\
& 2 & & & 6 & & \\
\hline
\end{tabular}

Berdasarkan perhitungan N-Gain diatas menunjukan bahawa rata-rata Skor N-Gain untuk kelas Eksperimen adalah sebesar 40,119 atau termasuk dalam kategori kurang efektif dengan nilai Skor N-Gain minimal adalah 0,00 dan masksimal 67,27. Sementara untuk rata-rata Skor N-Gain kelas kontrol sebesar 9,6536 yang termasuk kedalam kategori tidak efektif. Dengan nilai N-Gain skor minimal 0 dan Maksimal 47,06. Dengan demikian maka model penemuan terbimbing berbantuan web kurang efektif untuk meningkatakn keterampilan berpikir kritis matematis siswa. Sementara penggunaan model penemuan terbimbing konvensional tidak efektif untuk meningkatkan keterampilan berpikir kritis matematis siswa.

Selanjutnya, untuk mengetahui apakah ada perbedaan keefektifan antara model penemuan terbimbin berbantuan web dengan model penemuan terbimbing konvensional tersebut berarti signifikan (nyata) atau tidak, maka perlu dilakukan Uji Perbedaan ratarata. Adapun uji yang digunakan adalah uji Mann Whitney disebabkan karena skor NGain dari salah kelas tidak terdistribusi normal. 
Tabel 5. Uji Mann-Whitney N-Gain

\begin{tabular}{lll}
\hline & $\begin{array}{l}\text { Rata-Rata } \\
\text { Gain }\end{array}$ & $\mathrm{N}-$ \\
\hline Mann-Whitney U & 65.000 \\
Wilcoxon W & 593.000 \\
$\mathrm{Z}$ & -5.938 \\
Asymp. Sig. (2-tailed) & .000 \\
\hline
\end{tabular}

Berdasarkan tabel di atas dalam uji Mann-Whitney di atas diketahui bahwa nilai Asymp. Sig (2-tailed) sebesar 0,000 dimana nilai tersebut lebih kecil dari 0,05, oleh karena itu dapat dikatakan bahwa ada perbedaan N-Gain skor antara kelas eksperimen dengan kelas kontrol. Sehingga dapat ditarik sebuah kesimpulan yakni ada pengaruh penerapan model penemuan terbimbing berbantuan web terhadap keterampilan Berpikir kritis matematis siswa kelas X SMAN 4 Praya tahun 2019/2020.

\subsection{Pembahasan}

Penelitian ini bertujuan untuk mengetahui pengaruh model penemuan terbimbing berbantuan web terhadap keterampilan berpikir kritis matematis siswa kelas X SMAN 4 Praya. Keterampilan berpikir kritis matematis yang dimaksud meliputi kemampuan menginterpretasi, menganalisis, menarik kesimpulan, dan mengeksplanasi.

Pemilihan keempat indikator berpikir kritis yang meliputi interpretasi, analisis, kesimpulan, dan eksplanasi, didasarkan pada pertimbangan bahwa terdapat sebuah keterbatasan yaitu tidak semua indikator yang disampaikan oleh para ahli mudah untuk diukur. Selain itu, keterbatasan lainnya yaitu alokasi waktu di kelas yang hanya cukup untuk mendukung indikator yang terukur melalui teknik tes berupa pemberian soal uraian.

Pembelajaran menggunakan model penemuan terbimbing berbantuan web mempunyai pengaruh tehadap keterampilan berpikir kritis matematis siswa. Hal ini dibuktikan dengan adanya perbedaan skor rata-rata N-Gain yang ditunjukan dalam proses pembelajaran pada kelompok eksperimen dengan kelompok kontrol. Dalam pembelajaran ini siswa mampu menemukan sendiri konsep-konsep yang di butuhkan untuk memecahkan masalah yang diberikan sehingga mereka memperoleh pengetahuan yang baru dan lebih melekat.

Berdasarkan pedoman peningkatan N-Gain, kelas eksperimen berada memiliki peningkatan yang lebih baik dibanding dengan kelas kontrol. Dimana rata-rata $\mathrm{N}$-gain pada kelas eksperimen sebesar 40,119 sedangkan rata- kelas kontrol sebesar 9,65. Berdasarkan tabel tafsiran efektifitas N-Gain, maka dapat di lihat bahwa kelas eksperimen ditafsirkan berada pada kelompok kurang efektif. Sedangkan kelas kontrol berada pada kelompok tidak efektif. Faktor yang mempengaruhi hasil belajar kelas eksperimen adalah model pembelajaran yang digunakan. Dimana kelas eksperimen menggunakan model penemuan terbimbing (guided discovery) berbantuan web, sedangkan kelas kontrol menggunakan model penemuan terbimbing kovensional. 
Penggunaan model penemuan terbimbing pada kelas eksperimen memiliki dampak positif dalam meningkatkan keterampilan berpikir kritsi. Peningkatan keterampilan berpikir kritis siswa dengan menggunakan bantuan web lebih efektif dibandingkan dengan model penemuan terbimbing konvensional. Hal tersebut terlihat dari kenaikan rata-rata antara kelas yang melakukan proses penemuan menggunakan bantuan web dibanding tanpa menggunakan bantuan web. Hal ini dibuktikan dengan kenaikan ratarata pada kelas eksperimen dari 34,14 menjadi 60,48. Secara deskriptif nilai tersebut memilik peningkatan yang tinggi. Sedangkan pada kelas yang melaksanakn pembelajaran tanpa menggunakan web peninkatan dari 29,25 menjadi 34,75.

\section{SIMPULAN}

Berdasarkan uji yang telah dilakukan maka dapat disimpulkan bahawa terdapat pengaruh penggunaan model penemuan terbimbing berbantuan web terhadap keterampilan berpikir kirtis matematis siswa kelas X SMAN 4 Praya tahun 2019/2020.

\section{REFERENSI}

Abdullah, In Hi. (2013). Berpikir Kritis Matematik. Jurnal Matematika Dan Pendidikan Matematika Delta-Pi Jurusan MIPA FKIP Universitas Khairun, 2.

Arikunto, Suharsimi. (2006). Prosedur Penelitian Suatu Pendekatan Praktek. PT. Rineka Cipta.

Daryanto. (2016). Media Pembelajaran. Gava Media.

Emzir. (2017). Metodologi Penelitian Pendidikan Kuantitatif Dan Kualitatif. Rajawali Pers.

Irawati, Titiek. (2010). Pengelolaan Pembelajaran Matematika Berbsis Teknologi Informasi Untuk Meningkatkan Pemahaman Konsep Dimensi Tiga di SMKN 1 Sawit Boyolali.

Maulana. (2008). Pendekatan Metakognitif Sebagai Alternatif Pembelajaran Metematika Untuk Meningkatkan Kemampuan Berpikir Kritis Siswa PGSD. Jurnal Pendidikan Dasar, 39_ 46.

Mujib, Mardiyah. (2017). Kemampuan Berpikir Kritis Matematis Berdasarkan Kecerdasan Multiple Intelligences. Jurnal Pendidikan Matematika, 8, 187-196.

Rosha Media, Irwan Jas, Nilawasti. (2012). Penggunaan Media Pembelajaran Berbasis Website Dalam Pembelajaran Matematika. Jurnal Pendidikan Matematika FMIPA UNP 2(1), 15 .

Supatmono, Catur. (2009). Matematika Asyik. Grasindo.

Turmuzi, M. (2012). Strategi Pembelajaran Matematika. Fakultas Keguruan Dan Ilmu Pendidikan Universitas Mataram. 